\title{
Komponen Dinding Sel Indigofera (Indigofera zollingeriana) di Lahan Gambut Berdasarkan Umur Panen 2, 3, 4 dan 5 Bulan setelah Pemangkasan
}

\section{Cell Wall Components of Indigofera (Indigofera zollingeriana) in Peatlands Based on Harvest Age at 2, 3, 4 and 5 Months after Pruning}

\author{
A. Ali*, A. Rias, T. Adelina, \& R. Misrianti \\ Program Studi Peternakan Fakultas Pertanian dan Peternakan \\ Universitas Islam Negeri Sultan Syarif Kasim Riau \\ Jl. H.R. Soebrantas No. 155 Tuah Madani, Pekanbaru 28293 Riau, Indonesia \\ *Email korespondensi: arsyadi.ali@uin-suska.ac.id
}

- Diterima: 26 April 2021 • Direvisi: 16 Agustus 2021 • Disetujui: 17 Agustus 2021

\begin{abstract}
ABSTRAK. Penelitian ini bertujuan untuk mengetahui umur panen yang tepat dan kandungan neutral detergent fibre (NDF), acid detergent fibre (ADF), acid detergent lignin (ADL), hemiselulosa dan selulosa Indigofera zollingeriana (indigofera) di lahan gambut bertipe saprik berdasarkan umur panen 2, 3, 4 dan 5 bulan setelah pemangkasan. Indigofera yang digunakan pada penelitian ini adalah yang berumur $\pm 3,5$ tahun yang tumbuh pada lahan percobaan Laboratorium UIN Agriculture Research and Development Station (UARDS) Fakultas Pertanian dan Peternakan UIN Suska Riau. Rancangan penelitian yang digunakan adalah rancangan acak kelompok (RAK) yang terdiri dari 4 perlakuan dan 4 kelompok. Perlakuan terdiri dari: (1) Biomasa $I$. zollingeriana yang dipanen pada umur 2 bulan; (2) Biomasa I. zollingeriana yang dipanen pada umur 3 bulan; (3) Biomasa I. zollingeriana yang dipanen pada umur 4 bulan; (4) Biomasa I. zollingeriana yang dipanen pada umur 5 bulan. Hasil penelitian menunjukkan bahwa perbedaan umur panen 2,3,4 dan 5 bulan setelah pemangkasan tidak nyata $(P>0,05)$ mempengaruhi kandungan NDF, ADF, hemiselulosa dan selulosa I. zollingeriana, namun peningkatan umur panen dari 4 ke 5 bulan nyata $(\mathrm{P}<0,05)$ meningkatkan kandungan ADL I. zollingeriana dari 6,02\% ke 12,37\%. Berdasarkan data hasil penelitian dapat disimpulkan bahwa komponen dinding sel (fraksi serat) I. zollingeriana berupa NDF, ADF, hemiselulosa dan selulosa relatif stabil di lahan gambut bertipe saprik dengan peningkatan umur panen dari 2 ke 5 bulan setelah pemangkasan, namun kandungan ADL meningkat dengan nyata pada umur panen 5 bulan.
\end{abstract}

Kata kunci : Fraksi serat, gambut, indigofera zollingeriana, umur panen.

ABSTRACT. The purpose of this study was to determine the appropriate harvest age and the content of neutral detergent fiber (NDF), acid detergent fiber $(A D F)$, acid detergent lignin (ADL), hemicellulose and cellulose of Indigofera zollingeriana growth in sapric type peatlands based on harvest age of maturity $(2,3,4$ and 5 months) after pruning. Indigofera zollingeriana foliage was obtained from the existing plot that is a \pm 3.5 year old that grows in the research farm of the UIN Agriculture Research and Development Station Laboratory, Faculty of Agriculture and Animal Sciences, State Islamic University of Sultan Syarif Kasim Riau. The research design used was a randomized complete block design (RCBD) consisting of 4 treatments and 4 groups. The treatments were: (1) I. zollingeriana biomass harvested at 2 months of maturity; (2) I. zollingeriana biomass harvested at 3 months of maturity; (3) I. zollingeriana biomass harvested at 4 months of maturity; (4) I. zollingeriana biomass harvested at 5 months of maturity. The results showed that the differences in harvest age of I. zollingeriana at 2,3,4 and 5 months after pruning did not significantly (P>0.05) affect the content of NDF, ADF, hemicellulose and cellulose. However, the increase in harvest age of maturity from 4 to 5 months significantly $(P<0.05)$ increased the ADL content of I. zollingeriana from $6.02 \%$ to $12.37 \%$. Based on the research data, it can be concluded that the cell wall components of I. zollingeriana in the form of NDF, ADF, hemicellulose and cellulose were relatively stable on sapric type peatlands with an increase in harvest age from 2 to 5 months after pruning. However, the ADL content increased significantly at the 5 months of harvest age of maturity.

Key words: Fibre fractions, harvest age, indigofera zollingeriana, peatland.

\section{PENDAHULUAN}

Kecernaan hijauan pakan ternak sangat dipengaruhi oleh kandungan serat kasarnya.
Serat kasar merupakan bagian dari karbohidrat yang sulit dicerna. Tingkat kecernaan serat kasar sangat dipengaruhi oleh komponen dinding selnya berupa neutral detergent fibre (NDF), acid 
detergent fibre (ADF) dan acid detergent lignin (ADL)/lignin. Kandungan NDF, ADF dan lignin hijauan pakan ternak sangat dipengaruhi oleh umur panen (maturity). Semakin tua umur panen hijauan pakan ternak maka kandungan serat kasar semakin meningkatkan (Ali, 2013). Palmonari et al. (2014) melaporkan bahwa umur panen memengaruhi kandungan protein dan fraksi serat hay alfalfa, dimana penundaan umur panen meningkatkan kandungan fraksi serat. Hal ini diperkuat oleh Herdiawan et al. (2014) yang melaporkan bahwa peningkatan umur panen dari 60 hari ke 90 hari dapat meningkatkan kandungan fraksi serat (NDF dan ADF) I. zollingeriana, dimana kandungan NDF meningkat dari $37,78 \%$ menjadi $44,13 \%$ dan kandungan ADF meningkat dari 30,24\% menjadi $33,42 \%$. Ternak ruminansia memerlukan fraksi serat dalam pakannya untuk keperluan fungsi rumen dan untuk mendapatkan produktivitas yang maksimal. Proporsi kandungan NDF terbesar berasal dari hijauan (Mahyuddin dan Purwantari, 2009). Kandungan NDF suatu hijauan pakan ternak (HPT) menggambarkan perkiraan persentase material dinding sel. Kandungan NDF berbanding terbalik dengan intake. Pengukuran komponen dinding sel (fraksi serat) ini sangat penting, karena kandungan NDF yang lebih rendah akan mendorong konsumsi HPT yang lebih Tinggi.

Kandungan serat kasar hijauan pakan ternak juga dipengaruhi oleh tingkat kesuburan tanah. Hijauan pakan ternak yang ditanam pada tanah subur yang banyak mengadung $\mathrm{N}$ memiliki kandungan serat yang rendah. Nuraeni dkk. (2019) melaporkan bahwa rumput Paspalum stratum yang ditanam pada tanah dengan tingkat pemupukan yang tinggi maka menghasilkan peningkatan berat kering dan protein kasar, serta penurunan serat kasar. Tingkat kesuburan tanah juga sangat dipengaruhi oleh jenis tanah. Jenis tanah gambut mempunyai tingkat kesuburan yang lebih rendah dibandingkan dengan tanah mineral. Namun demikian pemanfaatan tanah gambut untuk pertanian saat ini sangatlah besar, karena lahan pertanian subur untuk budidaya pertanian semakin terbatas yang disebabkan oleh alih fungsi lahan pertanian subur. Pemanfaatan lahan gambut secara umum adalah untuk perkebunan (Masganti dkk., 2014). Luas lahan gambut Propinsi Riau lebih kurang 3,89 juta hektar atau sebanyak 59,94\% dari 6,49 juta hektar luas lahan gambut yang ada di pulau Sumatera dan telah dimanfaatkan untuk perkebunan dan budidaya tanaman pertanian (Darmawan dkk., 2016). Jenis gambut yang banyak dimanfaatkan untuk pertanian adalah gambut tipis dan bertipe saprik. Gambut saprik merupakan gambut yang paling matang dengan tingkat dekomposisi bahan organik yang paling tinggi, dicirikan oleh kandungan serabut paling rendah yakni $<33 \%$, berat isi $\geq 0,2$ g.cm ${ }^{-3}$, kandungan air $<450 \%$, warna kelabu sangat kelam-kelam hitam (Masganti dkk., 2017).

Pemanfaatan lahan gambut untuk budidaya hijauan pakan ternak dari kelompok leguminosa seperti Indigofera zollingeriana dan Leucane leucocephala telah dilaporkan oleh Ali et al. (2014), dimana produktivitas dan kandungan nutrisi I. zollingeriana di lahan gambut lebih tinggi dibandingan dengan L. leucocephala. Kandungan fraksi serat I. zollingeriana (29,6$40,7 \%$ ) yang ditanam di lahan gambut bertipe saprik adalah lebih rendah dibandingkan $L$. leucocephala (33,3-48,8\%). Hasil ini menunjukkan bahwa I. zollingeriana dapat tumbuh dengan baik di lahan gambut. Tingkatan umur panen dan lahan gambut merupakan 2 hal yang sangat memengaruhi produktivitas dan kualitas nutrisi hijauan. Semakin tua umur panen maka akan meningkatkan proporsi batang terhadap daun (Badarina, 2007) sehingga meningkatkan fraksi serat hijauan. Hal ini diperkuat oleh hasil penelitian Hutabarat dkk. (2017), dimana kandungan serat kasar Indigofera zollingeriana meningkat dari $20,72 \%$ menjadi $25,41 \%$ dengan peningkatan umur panen dari 40 hari ke 60 hari. Namun belum banyak dilaporkan berkenaan dengan kandungan fraksi serat Indigofera sp yang tumbuh di lahan gambut. Penelitian ini bertujuan untuk mengetahui umur panen yang tepat dan kandungan NDF, ADF, ADL, hemiselulosa dan selulosa Indigofera zollingeriana di lahan gambut bertipe saprik berdasarkan umur panen 2, 3, 4 dan 5 bulan setelah pemangkasan.

\section{MATERI DAN METODE}

\section{Materi dan Tempat Penelitian}

Indigofera zollingeriana yang digunakan pada penelitian ini adalah yang berumur $\pm 3,5$ tahun yang tumbuh di lahan percobaan Laboratorium UIN Agriculture Research and 
Development Station (UARDS) Fakultas Pertanian dan Peternakan UIN Suska Riau. Penilaian komponen dinding sel (NDF, ADF, ADL, hemiselulosa dan selulosa) biomasa $I$. zollingeriana dilaksanakan di Laboratoriun Nutrisi dan Teknologi Pakan Fakultas Pertanian dan Peternakan UIN Suska Riau.

\section{Plot, jarak tanam dan pemupukan}

Ukuran lahan yang digunakan pada penelitian ini adalah $13,5 \times 13,5$ pada tanah gambut bertipe saprik dan dibagi atas 4 kelompok dengan ukuran masing-masing kelompoknya $1.5 \mathrm{~m} \times 13,5 \mathrm{~m}$. Pengelompokan dibuat berdasarkan pencahayaan matahari. Ke empat kelompok ini membentuk segi 4, dengan 1 kelompok setiap sisinya. Jumlah indigofera pada masing-masing kelompok adalah 10 batang dengan jarak tanam 1,5 m. Pupuk dasar yang digunakan adalah kotoran sapi dengan dosis pemberian sebanyak 10 ton/ha yang diberikan 1 bulan sebelum triming. Pupuk NPK diberikan 2 minggu setelah triming dengan dosis $50 \mathrm{~kg}$ berdasarkan Ali et al. (2013).

\section{Pemangkasan, penandaan, pemanenan dan pengambilan sampel}

Pemangkasan dilakukan 2 bulan sebelum pengamatan dilakukan. Tanaman dipangkas $\pm 2,5 \mathrm{~cm}$ dari tempat tumbuhnya percabangan dengan menggunakan gunting tanaman. Hal ini dilakukan untuk mendapatkan pertumbuhan kembali (re-growth) yang seragam. Sebulan sebelum umur panen 2 bulan, dilakukan penandaan secara acak pada ranting (berdasarkan panjang ranting) menggunakan tali rafia dengan 4 warna yang berbeda. Penandaan dilakukan untuk mengetahui bagian ranting yang dipanen pada umur 2, 3, 4 dan 5 bulan. Pemanenan dilakukan dengan menggunakan gunting tanaman. Ranting/cabang yang dipanen dipilih berdasarkan tanda yang sudah diberikan dan dipotong $\pm 2,5 \mathrm{~cm}$ dari pangkal tempat tumbuhnya, dan langsung ditimbang untuk mendapatkan produksi segar. Kemudian diambil sampel sebanyak $500 \mathrm{~g}$ dari masingmasing bagian tanaman yang telah dipanen untuk keperluan analisa komponen dinding sel.

\section{Rancangan Penelitian}

Rancangan penelitian yang digunakan adalah rancangan acak kelompok (RAK) berdasarkan Gomez and Gomez (1984) yang terdiri dari 4 perlakuan dan 4 kelompok. Perlakuan terdiri dari: (1) Biomasa I. zollingeriana yang dipanen pada umur 2 bulan (2B); (2) Biomasa I. zollingeriana yang dipanen pada umur 3 bulan (3B); (3) Biomasa I. zollingeriana yang dipanen pada umur 4 bulan (4B); dan Biomasa $I$. zollingeriana yang dipanen pada umur 5 bulan (5B). Perlakuan umur panen dilakukan pada setiap 5 (lima) tanaman yang terdapat pada masing-masing kelompok dan dipanen sebanyak 4 kali berdasarkan umur panen. Pemilihan 5 tanaman pada masing-masing kelompok berdasarkan tanaman yang mempunyai percabangan/ranting yang terbanyak. Sebelum dilakukan panen pada umur 2 bulan, jumlah ranting yang tumbuh pada masing-masing tanaman dihitung untuk menentukan jumlah total ranting. Jumlah ranting yang dipanen pada setiap umur panen adalah $1 / 4$ (seperempat) dari jumlah total ranting yang ada pada setiap tanaman.

\section{Parameter Pengamatan}

Parameter yang diamati pada penelitian adalah kandungan NDF, ADF, ADL, hemiselulosa dan selulosa yang diukur berdasarkan metode Van Soest et al. (1991).

\section{Analisa Kandungan Nutrisi}

Sampel segar sebanyak 500 g (hasil komposit 5 tanaman) dari masing-masing perlakuan pada setiap kelompok dikeringkan dalam oven yang bersuhu $60^{\circ} \mathrm{C}$ selama 48 jam dan selanjutnya digiling untuk mendapatkan ukuran sampel yang seragam $(1 \mathrm{~mm})$ yang digunakan dalam menganalisa kandungan komponen dinding sel (NDF, ADF, ADL, hemiselulosa dan selulosa). Komposisi fraksi serat dihitung berdasarkan bahan kering dengan penentuan bahan kering sampel yang dikeringkan pada suhu $105^{\circ} \mathrm{C}$ selama 24 jam.

\section{Analisa Statistik}

Data hasil penelitian dianalisis dengan menggunakan analysis of variance (ANOVA) berdasarkan rancangan acak kelompok. Untuk 
mengetahui tingkat perbedaan nyata pada pelakuan, dilakukan uji Duncan's Multiple Range Test (DMRT) pada tingkat 5\%.

\section{HASIL DAN PEMBAHASAN}

\section{Kandungan Neutral Detergent Fibre (NDF)}

Beberapa peneliti telah melaporkan bahwa semakin tua HPT dipanen maka porsentase kandungan NDF semakin tinggi. Namun pada penelitian ini mendapatkan hasil yang berbeda untuk I. zollingeriana yang ditanam di lahan gambut bertipe saprik. Berdasarkan data pada Tabel 1. dapat dilihat bahwa perbedaan umur panen 2, 3, 4 dan 5 bulan memberikan hasil yang tidak berbeda nyata $(\mathrm{P}>0,05)$ terhadap kandungan NDF. Hasil ini menunjukkan bahwa kandungan NDF selain dipengaruhi oleh tingkatan umur panen juga sangat dipengaruhi jenis hijauan, genetik dan jenis tanah dan lingkungan tempat tumbuh (Mahyuddin, 2007; Ali et al., 2014; Herdiawan et al., 2014;
Kumalasari, 2017 et al., 2017; Lepcha et al., 2019). Secara umum konsentrasi NDF hijauan meningkat dengan bertambahnya umur tanaman. Kondisi ini disebabkan oleh semakin tua tanaman maka komponen dinding selnya semakin tinggi (Hutabarat et al., 2017). NDF merupakan komponen dinding sel yang terdiri dari hemiselulosa, $\mathrm{N}$ dinding sel dan ADF. Saddul et al. (2005) melaporkan bahwa penundaan umur panen mulberry dari 3 minggu ke 9 minggu nyata meningkatkan kandungan NDF dari $26,8 \%$ menjadi $54,4 \%$. Sementara itu Akpensuen et al. (2018) melaporkan juga bahwa peningkatan umur panen dari 9 minggu ke 21 minggu nyata meningkatkan kandungan NDF rumput Stylosanathes guianensis dari 40,29\% menjadi 49,44\%. Hasil ini diperkuat oleh Herdiawan et al. (2014) dimana peningkatan umur panen I. zollingeriana dari 60 hari ke 90 hari juga nyata menambah konsentrasi NDF sebesar 6,35\% (kandungan NDF meningkat dari 37,78\% menjadi $44,13 \%)$ pada perlakuan berbagai taraf stres kekeringan.

Tabel 1. Kandungan komponen dinding sel (fraksi serat) I. zollingeriana pada umur panen, 2, 3, 4 dan 5 bulan di lahan gambut

\begin{tabular}{cccccc}
\hline \multirow{2}{*}{$\begin{array}{c}\text { Umur Panen } \\
\text { (bulan) }\end{array}$} & NDF & ADF & ADL & Hemiselulosa & Selulosa \\
\cline { 2 - 6 } & $36,65 \pm 5,19$ & $25,88 \pm 3,72$ & $5,28^{\mathrm{a}} \pm 1,89$ & $10,77 \pm 4,94$ & $18,68 \pm 4,12$ \\
2 & $35,69 \pm 6,59$ & $24,29 \pm 4,54$ & $6,17 \mathrm{a} \pm 1,75$ & $11,39 \pm 3,27$ & $16,22 \pm 3,45$ \\
3 & $33,31 \pm 4,91$ & $25,93 \pm 2,14$ & $6,02^{\mathrm{a}} \pm 0,93$ & $7,38 \pm 2,94$ & $18,06 \pm 1,77$ \\
4 & $38,86 \pm 3,89$ & $29,33,4,47$ & $12,37 \mathrm{~b} \pm 3,96$ & $9,53 \pm 3,89$ & $16,04 \pm 2,20$ \\
5 &
\end{tabular}

Superskrip a, b pada kolom yang sama menujukkan perbedaan nyata $(\mathrm{P}<0,05)$.

\section{Kandungan Acid Detergent Fibre (ADF)}

Kandungan ADF menunjukan persentase bahan tanaman atau hijauan yang sangat sulit dicerna. ADF ini tidak larut dalam deterjen asam. ADF mengandung silika. Silika dan lignin pada tumbuhan dikaitkan dengan daya cerna yang rendah. Semakin rendah ADF, semakin banyak pakan yang dikonsumsi dan dicerna oleh ternak. Beberapa hasil penelitian menunjukkan hasil yang bervariasi terhadap kandungan ADF I. zollingeriana yang dipanen pada umur, kondisi lingkungan dan iklim yang berbeda. Pada penelitian ini (Tabel 1), peningkatan umur panen dari 60 hari (2 bulan) ke 150 hari ( 5 bulan) tidak nyata $(\mathrm{P}>0.05)$ meningkatkan kandungan ADF I. zollingeriana. Hal ini membuktikan bahwa kandungan ADF I. zollingeriana selain dipengaruhi oleh umur panen juga sangat dipengaruhi oleh kondisi lingkungan, iklim dan lahan tempat tumbuh. Walaupun secara umum konsentrasi fraksi serat seperti NDF, ADF dan ADL yang merupakan komponen dinding sel dan bagian dari karbohidrat yang sulit dicerna meningkat dengan bertambahnya umur tanaman. Hasil penelitian ini juga menunjukkan bahwa kandungan ADF yang ditanam di lahan gambut tipe saprik dengan kisaran 25,88-29,33\% (Tabel 1) adalah lebih rendah dibandingkan dengan hasil yang diperoleh oleh Herdiawan et al. (2014) dan Tantalo et al. (2019). Tantalo et al. (2019) melaporkan bahwa pada musim kemarau, penundaan umur panen dari 40 hari ke 55 hari nyata meningkatkan kandungan ADF $I$. zollingeriana dari $48,35 \%$ ke 56, 68\% dan nilai kandungan ADF nyata menurun ketika umur 
panen ditunda sampai umur 85 hari yaitu sebesar 49,41\%. Herdiawan et al. (2014) melaporkan hasil yang berbeda, dimana penundaan umur panen I. zollingeriana yang ditanam pada kondisi stres kering yang berbeda dari 60 hari ke 90 hari nyata meningkatkan rataan kandungan $\mathrm{ADF}$ dari 30,24\% ke 33,63\% dan ketika umur panen ditunda pada 90 hari rataan kandungan $\mathrm{ADF}$ tetap konstan yaitu sebesar $33,42 \%$.

\section{Kandungan Acid Detergent Lignin (ADL)}

Berdasarkan data pada Tabel 1. Dapat dilihat bahwa peningkatan umur panen dari 2 bulan ke 3 dan 4 bulan tidak nyata $(P>0,05)$ mempengaruhi kandungan ADL I. zollingeriana. Namun Kandungan ADL I. zollingeriana nyata $(\mathrm{P}<0,05)$ meningkat ketika umur panen ditingkatkan sampai umur 5 bulan. Hasil ini menujukkan bahwa pertumbuhan kembali (regrowth) I. zollingeriana 5 bulan setelah pemangkasan telah mengalami proses lignifikasi lanjut dan mengindikasikan bahwa sel tanaman telah matang (mature). Kematangan tanaman, berkorelasi dengan luasnya pengendapan lignin di jaringan tanaman (Nayan et al., 2019). Lignin sangat membatasi pemanfaatan (aksesibilitas) polisakarida (selulosa dan hemiselulosa) tanaman (Zhang et al., 2019) oleh ternak. Semakin tua tamanan maka kandungan lignin semakin tinggi (Meents et al., 2018) dan berdampak terhadap rendahnya kecernaan (Karkonen et al., 2014) dan rendahnya pemanfaatan komponen polisakarida seperti selulosa dan hemiselulosa hijauan oleh ternak. Grev et al. (2017) melaporkan bahwa ketika tanaman telah tua (matang) konsentrasi lignin meningkat, mengisi ruang antara selulosa, hemi selulosa, dan molekul pectin dan membentuk ikatan (cross-linkages) dengan hemiselulosa. Lignin disimpan di dinding sel tanaman sebagai bagian dari proses pematangan sel. Hal ini dibuktikan dengan terbentuknya jaringan kayu. Dan fungsi utama dari proses pengayuan (lignifikasi) pada tanaman adalah untuk memperkuat tubuh vascular tanaman.

\section{Kandungan Hemiselulosa}

Berdasarkan data Tabel 1. dapat dilihat bahwa perbedaan umur panen tidak mempengaruhi kandungan hemiselulosa $I$. zollingeriana secara nyata $(\mathrm{P}>0,05)$. Hal ini menunjukkan bahwa secara statistik peningkatan umur panen dari 2 ke 5 bulan belum memengaruhi konsentrasi polisakarida (hemiselulosa) yang mengisi ruang antara seratserat selulosa dalam dinding sel tanaman $I$. zollingeriana yang tumbuh di tanah gambut bertipe saprik. Hemiselulosa merupakan komponen dinding sel dan merupakan bagian dari serat kasar tanaman yang konsentrasinya dipengaruhi oleh jenis maupun kematangan (maturity) tanaman. Namun, tren perubahan kandungan hemiselulosa I. zollingeriana dengan peningkatan umur panen hasil penelitian ini tidak sejalan dengan peningkatan kandungan serat kasar tanaman yang secara umum meningkat nyata dengan penundaan umur panen tanaman. Herdiawan et al. (2014) melaporkan bahwa peningkatan umur panen $I$. zollingeriana dari 60 hari ( 2 bulan) ke 120 hari (4 bulan) pada kondisi 100\% kapasitas lapang nyata meningkatkan kandungan serat kasar dari $18,18 \%$ ke 22, 73\%. Konsentrasi hemiselulosa yang tinggi sangat diharapkan sebagai bahan sumber energi bagi ternak, karena hemiselulosa terdiri dari xilan, mannan, arabinogalaktan dan arabinan. Xilan adalah komponen utama hemiselulosa pada dinding sel tanaman (Supriyatna dan Putra, 2017), dan degradasi xilan akan menghasilkan xilosa yang mempunyai potensi sebagai komponen sumber energi bagi ternak ruminansia (Lamid dkk., 2006).

\section{Kandungan Selulosa}

Selulosa merupakan komponen utama penyusun dinding sel tanaman. Kandungan selulosa pada dinding sel tanaman tingkat tinggi sekitar $35-50 \%$ dari berat kering tanaman. Selulosa adalah zat penyusun tanaman yang terdapat pada struktur sel. Kadar selulosa dan hemiselulosa pada tanaman pakan yang muda mencapai 40\% dari bahan kering (Fitriani dkk., 2018) dan konsentrasinya dipengaruhi oleh jenis tanaman dan tingkatan umur panen. Sama halnya dengan hemiselulosa, konsentrasi yang tinggi dari selulosa sangat diharapkan sebagi sumber energi bagi ternak ruminansia. Namun dengan bertambahnya umur tanaman, akses ternak untuk mendapatkan selulosa dari hijauan semakin sulit karena adanya proses lignifikasi 
dan secara umum selulosa terikat dengan lignin (lignoselulosa). Sehingga umur panen yang tepat sangat memengaruhi ketersediaan selulosa bagi ternak ruminansia. Hasil penelitian ini menunjukkan bahwa penundaan umur panen $I$. zollingeriana dari 2 ke 5 bulan tidak memengaruhi secara nyata $(\mathrm{P}>0,05)$ kandungan selulosa. Hasil ini menunjukkan bahwa konsentrasi selulosa I. zollingeriana dengan rentang panen 2-5 bulan kandungan selulosanya relatif stabil. Namun demikian akses ternak untuk mendapatkannya semakin sulit, karena terjadinya peningkatan kandungan lignin secara nyata $(\mathrm{P}<0,05)$ dengan peningkatan umur panen dari 2-5 bulan (Tabel 1). Besarnya konsentrasi selulosa dan lignin merupakan salah satu kriteria yang menunjukkan kekuatan serat (Mudyantini, 2008).

\section{KESIMPULAN DAN SARAN}

Berdasarkan data hasil penelitian dapat disimpulkam bahwa komponen dinding sel (fraksi serat) I. zollingeriana berupa NDF, ADF, hemiselulosa dan selulosa relatif stabil di lahan gambut bertipe saprik dengan peningkatan umur panen dari 2 ke 5 bulan setelah pemangkasan. Namun kandungan ADL nya meningkat dengan nyata pada umur panen 5 bulan. Untuk itu disarankan, penundaan umur panen I. zollingeriana di lahan gambut bertipe saprik dilakukan paling lambat pada umur 4 bulan setelah pemangkasan.

\section{KONFLIK INTERES}

Tidak ada konflik kepentingan yang berkaitan dengan pribadi, keuangan atau lainnya dengan perseorangan atau organisasi terkait dengan materi yang dibahas pada artikel ini.

\section{DAFTAR PUSTAKA}

Akpensuen TT, Luka JS, Okpanachi U, Ishiaku YM and Munza BM. 2018. Effects of stage of growth on dry matter yield and nutrients composition of stylo (Stylosanthes guianensis cv. Cook) in Vom, Plateau State, Nigeria. Nig. J. Anim. Sci. Tech. 1(2):19-28.

Ali A. 2013. Teknologi pengawetan (hay) dan kualitas nutrisi murbei (Morus alba) yang ditanam di lahan gambut sebagai pakan ternak ruminansia. Kutubkhanah. 16(1):27-36.

Ali A, Abdullah L, Karti PDMH, Chozin MA and Astuti DA. 2013. Production, competition indices, and nutritive values of Setaria splendida, Centrosema pubescens, and Clitoria ternatea in mixed cropping systems in peatland. Media Peternakan. 36(2):209-215.

Ali A, Abdullah L, Karti PDMH, Chozin MA and Astuti DA. 2014. Production and nutritive value of Indigofera zollingeriana and Leucaena leucocephala in peatland. Animal Production. 16(3):156-164.

Badarina I. 2007. Produksi rumput tebu salah (Phragmites Sp.) sebagai sumber hijauan pakan potensial pada berbagai umur pemotongan. Jurnal Sain Peternakan Indonesia. 2(2):49-52.

Darmawan B, Siregar YI, Sukendi dan Zahrah S. 2016. Pengelolaan keberlanjutan ekosistem hutan rawa gambut terhadap kebakaran hutan dan lahan di semenanjung Kampar, Sumatera. J. Manusia dan Lingkungan. 23(2):195-205.

Fitriani, Rauf J, Novieta ID, Syahril MR. 2018. Kandungan selulosa, hemiselulosa dan lignin pakan komplit berbasis tongkol jagung yang disubtitusi Azolla pinnata pada level yang berbeda. Jurnal Galung Tropika. 7(3):220-228.

Gomez KA and Gomez AA. 1984. Statistical procedures for agricultural research $\left(2^{\text {nd }} \mathrm{Edn}\right)$. An International Rice Research Institute Book. A Willey-Interscience Publication, John Wiley and Son, USA. 680p.

Grev AM, Wells MS, Samac DA, Martinson KL, and Sheaffer CC. 2017. Forage accumulation and nutritive value of reduced lignin and reference alfalfa cultivars. Agron. J. 109(6):2749-2761.

Herdiawan I, Abdullah L, dan Sopandi D. 2014. Status Nutrisi Hijauan Indigofera zollingeriana pada Berbagai Taraf Perlakuan Stres Kekeringan dan Interval Pemangkasan. JITV. 19(2):91-103.

Hutabarat J, Erwanto, dan Wijaya AK. 2017. Pengaruh umur pemotongan terhadap kadar protein kasar dan serat kasar Indigofera zollingeriana. Jurnal Riset dan Inovasi Peternakan. 1(3):21-24.

Karkonen A, Tapanila T, Laakso T, Seppanen MM, Isolahti $\mathrm{M}$, Hyrkas $\mathrm{M}$, Virkajarvi $\mathrm{P}$, and Saranpaa. 2014. Effect of lignin content and subunit composition on digestibility in clones of timothy (Phleum pratense L.). J.Agric. Food Chem. 62 (26):6091-6099.

Kumalasari NR, Wicaksono GP and Abdullah L. 2017. Plant growth pattern, forage yield, and quality 
of Indigofera zollingeriana influenced by row spacing. Media Peternakan 40 (1):14-19.

Lamid M, Chuzaemi S, Ni Nyoman Tri Puspaningsih $\mathrm{Ni} \mathrm{N} \mathrm{T}$ dan Kusmartono. Inokulasi Bakteri Xilanolitik Asal Rumen sebagai Upaya Peningkatan Nilai Nutrisi Jerami Padi. Jurnal Protein.14 (2):122-128.

Lepcha I, Naumann HD, Fritschi FB, and Kallenbach RL. 2019. Herbage Accumulation, Nutritive Value, and Regrowth Potential of Sunn Hemp at Different Harvest Regimens and Maturity. Crop Sci. 56: 1-9.

Mahyuddin P. 2007. Chemical composition of leaf and stem of tropical grasses at different stage of growth. Animal Production 9 (3): 153-159.

Mahyuddin P and Purwantari ND. 2009. The neutral detergent fiber digestibility of some tropical grasses at different stage of maturity. Animal Production 11 (3):189-195.

Masganti, Wahyunto, Dariah A, Nurhayati dan Yusuf R. 2014. Karakteristik dan Potensi Pemanfaatan Lahan Gambut Terdegradasi di Provinsi Riau. Jurnal Sumberdaya Lahan. 8 (1):59-66.

Masganti, Anwar K dan Susanti MA. 2017. Potensi dan pemanfaatan lahan gambut dangkal untuk pertanian. Jurnal Sumberdaya Lahan. 11 (1):4352.

Meents MJ , Watanabe Y, and Samuels AL. 2018. The cell biology of secondary cell wall biosynthesis. Annals of Botany. 121:1107-1125.

Mudyantini W. 2008. Pertumbuhan, kandungan selulosa, dan lignin pada rami (Boehmeria nivea L. Gaudich) dengan pemberian asam giberelat $\left(\mathrm{GA}_{3}\right)$. Biodiversitas. 9(4): 269-274.

Nayan N, van Erven G, Kabel MA, Sonnenberg ASM, Hendriksa WH, and Conea JW. 2019. Improving ruminal digestibility of various wheat straw types by white-rot fungi. J.Sci. Food Agric. 99:957-965.
Nuraeni A, Khairani L, dan Susilawati I. 2019. Pengaruh tingkat pemberian pupuk nitrogen terhadap kandungan air dan serat kasar Corchorus aestuans. Pastura 9 (1):32-35.

Palmonari A, Fustini M, Canestrari G, Grilli E, and Formigoni A. 2014. Influence of maturity on alfalfa hay nutritional fractions and indigestible fiber content. Journal of Dairy Science 97 (12): 7729-7734.

Saddul D, Jelan ZA, Liang JB, and Halim RA. 2005. Evaluation of mulberry (Morus alba) as potential feed supplement for ruminants: The effect of plant maturity on in situ disappearance and in vitro intestinal digestibility of plant fractions. Asian-Aust. J. Anim. Sci. 18 (11):1569-1574.

Supriyatna A dan Putra RE. 2017. Estimasi pertumbuhan larva lalat black soldier (Hermetia illucens) dan penggunaan pakan jerami padi yang difermentasi dengan jamur $P$. Chrysosporium. Jurnal Biodjati. 2(2):159-166.

Tantalo S, Liman, Fathul F. 2019. Efek umur pemangkasan indigofera (Indigofera zollingeriana) pada musim kemarau terhadap kandungan neutral detergent fibre dan acid detergent fibre. Jurnal Ilmiah Peternakan Terpadu. 7(2): 241-246.

Van Soest PJ, Robertson JB, and Lewis BA. 1991. Methods for dietary fiber, neutral detergent fiber and non-starch polysaccharides in relation to animal nutrition. J. Dairy Sci. 74:3583-3593.

Zhang Y, Legland D, El Hage F, Devaux M-F, Guillon F, Reymond M, Me'chin V. 2019. Changes in cell walls lignification, feruloylation and $\mathrm{p}$ coumaroylation throughout maize internode development. PLoS ONE. 14(7):1-21. 